\title{
Ancient clam gardens, traditional management portfolios, and the resilience of coupled human-ocean systems
}

\author{
Julia Jackley $^{1}$, Lindsay Gardner $^{2}$, Audrey F. Djunaedi $^{2}$ and Anne K. Salomon ${ }^{2}$
}

\begin{abstract}
Indigenous communities have actively managed their environments for millennia using a diversity of resource use and conservation strategies. Clam gardens, ancient rock-walled intertidal beach terraces, represent one example of an early mariculture technology that may have been used to improve food security and confer resilience to coupled human-ocean systems. We surveyed a coastal landscape for evidence of past resource use and management to gain insight into ancient resource stewardship practices on the central coast of British Columbia, Canada. We found that clam gardens are embedded within a diverse portfolio of resource use and management strategies and were likely one component of a larger, complex resource management system. We compared clam diversity, density, recruitment, and biomass in three clam gardens and three unmodified nonwalled beaches. Evidence suggests that butter clams (Saxidomus gigantea) had 1.96 times the biomass and 2.44 times the density in clam gardens relative to unmodified beaches. This was due to a reduction in beach slope and thus an increase in the optimal tidal range where clams grow and survive best. The most pronounced differences in butter clam density between nonwalled beaches and clam gardens were found at high tidal elevations at the top of the beach. Finally, clam recruits $(0.5-2 \mathrm{~mm}$ in length) tended to be greater in clam gardens compared to nonwalled beaches and may be attributed to the addition of shell hash by ancient people, which remains on the landscape today. As part of a broader social-ecological system, clam garden sites were among several modifications made by humans that collectively may have conferred resilience to past communities by providing reliable and diverse access to food resources.
\end{abstract}

Key Words: ancient shellfish mariculture; bivalves; clam gardens; management portfolio; resilience; resource management; traditional marine management

\section{INTRODUCTION}

Mounting evidence suggests that diversity and functional redundancy within ecosystems, social systems, and management systems are key factors that confer resilience to social-ecological systems (Holling 1973, Folke et al. 1996, 2004, Low et al. 2003, Folke 2006). Because social and ecological systems are intimately linked and constantly in flux, flexible and diverse management strategies can foster learning and adaptation to external disturbances (Carpenter and Gunderson 2001, Peterson et al. 2003, Folke et al. 2005). Specifically, the diversification of resource use in conjunction with multiple management strategies can be used to cope with unanticipated shocks to these systems, such as sudden climate shifts, natural disasters, and dramatic changes in resource availability (Berkes and Folke 2003, Olsson et al. 2004). A growing body of evidence reveals that indigenous communities in North America developed a portfolio of diverse technologies and management strategies over millennia to enhance food production and increase food security (e.g., Anderson 2005, Deur and Turner 2005, Trosper 2009, Fowler and Lepofsky 2011, Smith 2011, Turner 2014).

Diverse and sophisticated conservation and management strategies were created, modified, and maintained by indigenous communities over hundreds, even thousands of years, allowing for the development of responses to both long and short-term perturbations (Berkes et al. 2000, Turner et al. 2000, Berkes and Turner 2006, Berkes 2012). These systems evolved as experience and traditional knowledge directed the learning, experimentation, and adaptation of these physical technologies and practices through time and across space. Many of these traditional management systems have left structural and cultural legacies we can observe today. These structural features and associated governance protocols provide an opportunity to examine how they might have functioned to confer resilience to socialecological systems in the past and how they might be retooled to help address today's management challenges.

Along the northwest coast of North America, emerging evidence suggests that indigenous communities, referred to as First Nations in Canada, developed a suite of technologies to conserve and manage resources within diverse nearshore habitats (Turner 2014). For example, along temperate shorelines, root gardens were tended to increase crop yields of northern rice root (Fritillaria camschatcensis), springbank clover (Trifolium wormskioldii), and Pacific silverweed (Potentilla anserina ssp. pacifica; Deur 2005). Terrestrial resources including various shrubs and trees were also tended, pruned, and fertilized to increase berry and fruit production (Thornton 1999, Trusler and Johnson 2008). Landscapes were routinely cleared and burned to promote the productivity of successional plant species (Boyd 1999, Lepofsky et al. 2005a), such as the underground edible bulbs of camas (Camassia spp.), one of the most widely traded food resources in the Pacific Northwest (Turner and Turner 2007). In coastal aquatic ecosystems, stone fish traps at the mouths of rivers (White 2006, Brown and Brown 2009) and wooden fish weirs within streams were constructed by Haida and Heiltsuk First Nations (Brown and Brown 2009, Kii'iljuus Wilson and Luu Gaahlandaay Borserio 2011) and were used to selectively harvest all five species and specific sizes of Pacific salmon. Large individuals were intentionally allowed to escape the fishery to increase the robustness of the next generation (Brown and Brown 2009). Specific hook sizes (Brown and Brown 2009) and net mesh were

\footnotetext{
${ }^{1}$ Department of Archaeology, Simon Fraser University, ${ }^{2}$ School of Resource and Environmental Management, Simon Fraser University
} 
employed to regulate the species and size of a catch (Lepofsky and Caldwell 2013). Among the Heiltsuk First Nation, the impact of harvests were also limited by restricting access to productive gathering sites based on family lineages (Powell 2012). Ancient clam gardens, a newly documented form of ancient mariculture technology (Harper et al. 1995, Williams 2006, Groesbeck et al. 2014, Lepofsky et al. 2015), may have been the basis for yet another form of ancient resource management embedded within a portfolio of coastal management practices.

Clam gardens are intertidal rock-walled terraces engineered by humans in ancient times and have been documented from northwest Washington, through British Columbia, to southeast Alaska (Harper et al. 1995, Harper and Morris 2004, Harper 2007, Williams 2006, Caldwell et al. 2012, Deur et al. 2015). These rock walls were constructed in the mid-intertidal zone, between 0.5-1.8 $\mathrm{m}$ above chart datum (LLWLT: lowest low water large tide; Groesbeck et al. 2014), and are associated with a beach terrace landward of the wall. It is hypothesized that these rock walls transformed naturally sloping clam beaches into more levelled terraces through a combination of natural sedimentation (Harper 2007) and the active addition of gravel and shell hash by people (Groesbeck et al. 2014). Similar to other resource management features and systems, clam gardens were embedded within a broader set of governance rules that guided management and use of associated land and seascapes (Lepofsky and Caldwell 2013, Deur et al. 2015, Lepofsky et al. 2015).

Written information on clam garden antiquity, ecological function, use, and management is just now accumulating (Williams 2006, Groesbeck et al. 2014, Deur et al. 2015, Lepofsky et al. 2015) and builds on the traditional knowledge held by First Nations people (Deur et al. 2015, Lepofsky et al. 2015). Recent archaeological excavations in southern British Columbia indicate that clam gardens date to at least 1000 years Before Present (B.P.; Lepofsky et al. 2015). Observational and transplant experiments comparing clam gardens and nonwalled beaches have demonstrated that clam gardens, by flattening the slope of the beach, expand clam habitat at the tidal height at which clams grow and survive best (Groesbeck et al. 2014). By extending the optimal growing conditions for clams, clam gardens have increased densities and biomass of native littleneck clams (Leukoma staminea). However, it is not yet clear how clam gardens affect clam community composition and recruitment and how they may have operated in conjunction with other traditional management policies governing the coastal land and seascape continuum. We contribute to this growing body of research by quantifying the variation in clam recruitment, diversity, density, and biomass between clam gardens and unmodified, nonwalled beaches on the central coast of British Columbia, Canada (Fig. 1) and by documenting the diverse eco-cultural landscape within which clam garden technology was embedded. Specifically, we build on previous work by Groesbeck et al. 2014 by (1) testing the generality of their hypotheses and evidence of increased production in a different biocultural region of Canada's Pacific coast and by (2) placing clam gardens within a broader context of coastal management technologies to explore how this ancient management technique may have conferred resilience within a portfolio of diverse ancient coastal management policies.

\section{METHODS}

\section{Study area}

\section{Ecological context}

This research was conducted on the central coast of British Columbia, Canada, in Kwakshua Channel between Calvert and Hecate islands (Fig. 1). Kwakshua Channel is $12 \mathrm{~km}$ long and is characterized by its steep, rocky intertidal zone and deep waters. Several sheltered inlets punctuate the western end of the channel and provide relatively shallow water and soft sediment beaches encompassing clam habitat. The dominant bivalves found in these beaches include butter clams (Saxidomus gigantea), macoma clams (Macoma spp.), native littleneck clams (Leukoma staminea), horse clams (Tresus spp.), eastern soft shell clams (Mya arenaria), and heart cockles (Clinocardium nuttallii). At the head of the inlets are small, lake-fed creeks and rivers flowing out to productive eelgrass habitats. Within $50 \mathrm{~m}$ to $1 \mathrm{~km}$, the exposed outer coast encompasses productive rocky intertidal and subtidal kelp forest habitat that together support a diversity of reef associated fish including lingcod (Ophiodon elongatus), rock fish (Sebastes spp.), and greenling (Hexagrammidae), and invertebrates, such as northern abalone (Haliotis kamtschatkana), sea urchin (Strongylocentrotus spp.), marine snails (Astrea gibgerosa, Littorina spp., Nucella spp.), mussels (Mytilus spp.), limpets (Acmaea spp., Lottiidae), chitons (Polyplacophora), and barnacles (Semibalanus spp., Balanus spp.).

Fig. 1. Kwakshua Channel, located between Calvert and Hecate islands, on the central coast of British Columbia, Canada encompasses a diversity of archaeological features (Table 1) and evidence of ancient marine use and management, including eight clam gardens. Radiocarbon dates suggest that people inhabited this region during the early Holocene, from at least 8000-10,000 years B.P. (McLaren and Christensen 2014).

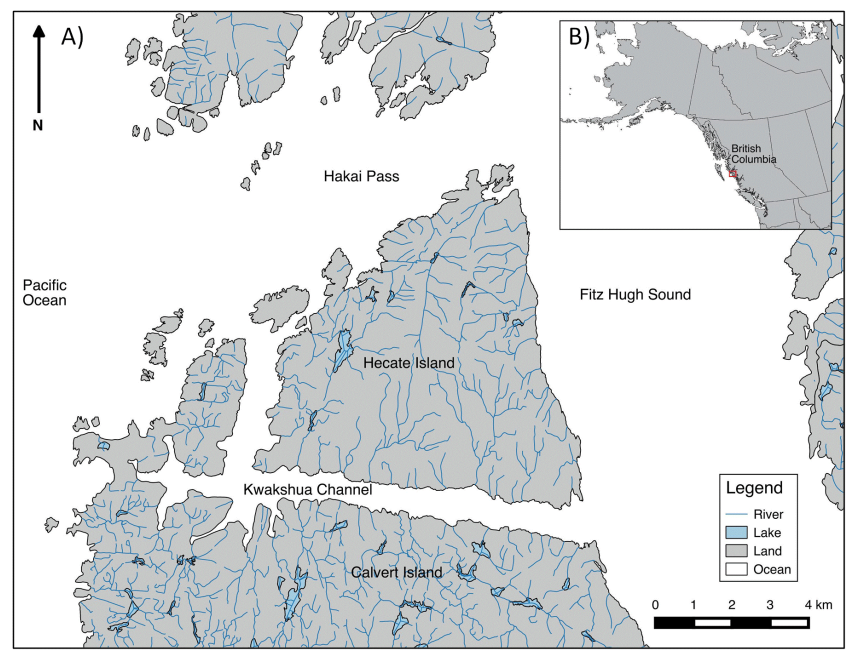

Above the surrounding foreshore is temperate rainforest characteristic of the hypermaritime variants of the Coastal Western Hemlock biogeoclimatic zone (Meidinger and Pojar 1991). This very wet hypermaritime forest covers much of the outer coast of British Columbia and is characterized by high rates of precipitation, cool summers, and wet winters (Meidinger and 
Pojar 1991) and is comprised of primary growth western red cedar (Thuja plicata) and yellow-cedar (Cupressus nootkatensis), western hemlock (Tsuga heterophylla), Sitka spruce (Picea sitchensis), and amabilis fir (Abies amabilis) trees. Bog forests and wetlands have developed in areas of low relief and are associated with high densities of sphagnum moss and stunted yellow-cedar, mountain hemlock (Tsuga mertensiana), and lodgepole pine (Pinus contorta). Together, the diverse terrestrial and highly productive maritime landscapes provide habitats for a wide range of species and thus resource use and a portfolio of ancient management technologies.

\section{Cultural context}

Archaeological research indicates that people have lived on the central coast of British Columbia, Canada continuously since at least 10,000 B.P. (Hester and Nelson 1978, Carlson 1979, 1996, Cannon 1991, 2000, McLaren and Christensen 2014, McLaren et al. 2015) and that they used a range of seasonally available marine and terrestrial species (Pomeroy 1980, Cannon and Yang 2006, Cannon et al. 2008, 2011). Faunal analyses of shell middens indicate that a wide variety of fish, marine mammals, and shellfish, including butter clam, native littleneck, horse clam, cockle, whelk (Nucella spp.), sea urchin, barnacle, limpet, mussel, and chiton were harvested. Site-specific patterns suggest an emphasis on local resource procurement (Cannon et al. 2008, 2011) and indicate that the seasonal harvest of clams varied among sites (Cannon and Burchell 2009, Burchell et al. 2013). In Kwakshua Channel, archaeological sites with sequences that span the early to late Holocene provide evidence of long-term occupation and connection to place (McLaren et al. 2015). The presence of at least four large village sites and many marine resource harvesting and processing sites (McLaren and Christensen 2014) suggests that the area was densely populated in the past. Furthermore, oral histories by First Nations identify Luxvbalis as a large winter village at the head of Kwakshua Channel (Olson 1955).

\section{Shoreline survey}

We documented the presence of human-made intertidal features in Kwakshua Channel, British Columbia, Canada (Fig. 1) with systematic boat-based surveys conducted during two low tides in the spring of 2012. Features including clam gardens, stone fish traps, canoe runs (small clearings free of large rocks that allow for the passage of canoes), and cleared clam beaches (the removal of rocks and boulders from the beach surface) were documented. We also documented upper intertidal and shoreline features (e.g., root garden, shell midden) along the southeastern most inlet in May 2013 and summarized data from previous archaeological surveys that include sites on north Calvert Island and west Hecate Island (Hobler 1988, Stryd et al. 1993, McLaren and Christensen 2014). All documented archaeological features, including clam gardens and nonwalled clam beaches, and new and previously recorded archaeological sites were compiled, geo-referenced with GPS, mapped using QGIS freeware, photographed, and described.

\section{Field surveys}

To quantify differences in clam diversity, biomass, density, and recruitment between clam gardens and nonwalled clam beaches, we measured and identified clams in $25 \times 25 \times 25 \mathrm{~cm}$ sample columns $\left(0.0156 \mathrm{~m}^{3}\right)$ along a vertical transect in replicate clam gardens $(n=3)$ and nonwalled beaches $(n=3)$ in May 2013 (Fig. 2). Vertical transects ran perpendicular to the shore, extending from the top of the clam habitat in the high intertidal to the rock wall in clam gardens or to $0.8 \mathrm{~m}$ above Canadian chart datum at nonwalled beaches, which was the average tidal height of the three clam garden rock walls sampled in Kwakshua Channel. A total of 15 evenly spaced and stratified tidal stations were established along the length of each transect. Tidal station 1 represents the top of clam habitat, whereas tidal station 15 is at the lowest intertidal height. Sample columns were then excavated at each tidal station. In some cases, columns could not be excavated to $25 \mathrm{~cm}$ depth because of the presence of rocks. In these cases, the depth of each excavation was recorded and measures of density were adjusted accordingly. The contents of each sample column were screened using 1/8-inch mesh to recover all live clams present. For $30 \%$ of the surveyed bivalves for which direct field biomass measurements were not possible because of tide constraints, we estimated their biomass by a length-weight regression (Appendix $1)$.

Fig. 2. We surveyed clams across vertical transects that ran from the top of clam habitat to $0.8 \mathrm{~m}$ above chart datum in both clam gardens $(n=3)$ and nonwalled clam beaches $(n=3)$. All visible clams in $25 \times 25 \times 25 \mathrm{~cm}$ samples $(\mathrm{n}=15$ per beach, represented by blue and green dots) were identified and measured. Based on previously published work on clam gardens elsewhere in British Columbia, we predicted that nonwalled beaches (A) would have a steeper slope and less area within optimal intertidal clam habitat (red box) compared to clam gardens (B). Redrawn from Groesbeck et al. 2014.

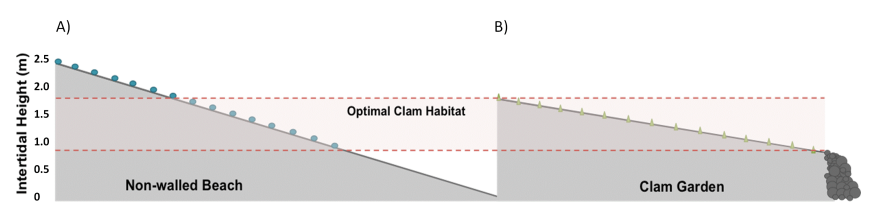

To quantify differences in bivalve recruitment between clam gardens and nonwalled beaches, we subsampled sediment from tidal stations $1,5,11$, and 15 from each site. The sediment was sifted through a 1/16-inch mesh screen to remove larger rocks and debris and a wet-screening process was used to remove the remaining silt and sand. A $1 / 4$ subsample was hand sorted on a tray to recover live clam recruits. After remixing the subsample, we conducted a second sort for any additional clam recruits and counted all macroscopic clam recruits visible to the naked eye $(\geq$ $0.5 \mathrm{~mm}$ ). The clam recruits were binned into two size categories, $<$ $2 \mathrm{~mm}$ and $2-5 \mathrm{~mm}$, to differentiate between those that might have settled in the year they were observed and those that likely settled late in the previous year.

\section{Statistical analysis}

Clam recruitment, biomass, and density

To assess whether differences exist in clam biomass and density between clam gardens and nonwalled beaches, we used linear mixed-effects models (LME), where beach type (clam garden vs. nonwalled beach) and tidal station (stations 1-15) were treated as fixed effects, and site was treated as a random effect. We used an 
interaction term of beach type * tidal station as an additional fixed effect in the models to test whether differences between beach type varied by tidal station. Beach type was selected to test for a clam garden effect, and beach type * tidal station interaction was selected to test for across-beach effects of tidal station between clam gardens and nonwalled beaches. We constructed these models for butter clams, native littleneck clams, and bentnose macoma (Macoma nusata) because these species composed the majority of clams found. We also constructed linear models to examine patterns in clam recruitment between clam gardens and nonwalled beaches. Variance structures were assessed and selected for each model based on the Akaike information criterion, corrected for small sample size (AIC $\mathrm{A}_{\mathrm{c}}$; Burnham and Anderson 2002). Final models met homoscedastic variance and normality assumptions. Although tidal stations were spatially autocorrelated along each transect, we found that adding correlation structures to clam biomass and density models did not improve the fit of our models.

We competed models with all possible combinations of fixed factors and determined the relative support for each model using $\mathrm{AIC}_{\mathrm{c}}$. Models were standardized to the best-fit and most parsimonious model to determine $\Delta \mathrm{AIC}_{\mathrm{c}}$ values, with the lowest values having the best compromise between model fit and number of parameters (Burnham and Anderson 2002). The $\Delta \mathrm{AIC}_{\mathrm{c}}$ values $\leq 2$ show substantial support for a given model over others. Akaike weights $\left(\mathrm{w}_{\mathrm{i}}\right)$ were calculated as the ratio of $\Delta \mathrm{AIC}_{\mathrm{c}}$ values for each model relative to the entire set of candidate models. All models were constructed and analyzed in R (R Core Team 2014).

\section{Optimal clam habitat models}

To assess if and how clam garden engineering altered intertidal height and optimal growing conditions for clams, we modeled the relationship between intertidal height and the biomass and density of clams in clam gardens and nonwalled beaches, by fitting Gaussian models (Eq. 1) to clam biomass and density (y) as a function of intertidal height:

$$
y=\alpha * e^{-0.5\left(\frac{x-\mu}{\sigma}\right)^{2}}
$$

where $\alpha$ (curve height) describes the magnitude of clam biomass or density, $\mu$ (curve mean) is the intertidal height at which biomass or density is greatest, and $\sigma$ (curve width) describes the standard deviation in clam biomass or density. We then compared fitted model parameters across clam gardens and nonwalled beaches based on our predictions (Appendix 2).

\section{Hypotheses}

Based on previous research (Groesbeck et al. 2014), we predicted that clam gardens expand the amount of optimal clam habitat by reducing the slope of the beach relative to nonwalled clam beaches (Fig. 2), thereby increasing the area of habitat situated within optimal tidal height for clams. Thus, we expected to find greater biomass and density of clams particularly at the higher tidal stations of clam gardens compared to nonwalled beaches. In addition, we predicted that Gaussian models of clam biomass and density would peak at approximately the same tidal height $\mu$ but would differ in their maximum height $\alpha$ such that biomass and density would be elevated in clam gardens because of differences in sediment composition and water retention afforded by the rock wall. Finally, we predicted that clam recruitment would be enhanced in clam gardens compared to nonwalled beaches due to an expanded range of optimal clam habitat and superior shell hash substrate known to induce the settlement of pelagic larval clams and improve conditions for their growth and survival post settlement (Butman et al. 1988, Green et al. 2013). We expected that the greatest differences in clam abundance and recruitment between site types would occur near the top and bottom of sampled beaches because these are the areas that would be most affected by a change in beach slope. Although we expected the biomass and density of clams to vary between clam gardens and nonwalled beaches, we did not expect species composition to differ.

\section{RESULTS}

\section{Evidence of ancient human landscape modification and use}

We surveyed 32 kilometers of coastline from the intertidal $(0 \mathrm{~m}$, i.e. chart datum) to the foreshore (approximately $7 \mathrm{~m}$ above chart datum). We documented previously unrecorded anthropogenic modifications to the landscape, including eight clam gardens (Fig. $3 \mathrm{~A})$, three cleared clam beaches with no wall that appeared to be anthropogenically altered with most stones removed or moved shoreward (Fig. 3B), a possible root garden (Fig. 3C), two stone fish traps (Fig 3D), a canoe run, and a shell midden site with an associated artifact (Table 1). We also recorded 16 unmodified nowalled clam beaches with no observable human modifications. Previous surveys of this area have documented an additional 24 shell middens, 18 culturally modified tree sites, 9 intertidal lithic scatters, 7 rock art sites, 5 canoe runs, 4 stone fish traps, 4 villages, 2 clam gardens, a burial site, and a defensive site (Pomeroy 1980, Hobler 1988, Stryd et al. 1993, White 2006, McLaren and Christensen 2014) (Table 1).

We identified clam gardens and cleared beaches in various habitats and observed that their sediment composition and slope differed from nonwalled beaches. The clam gardens were found along the mouths and/or edges of small inlets, had shallower slopes compared to unaltered beaches (Fig. 4), and their sediment was primarily composed of shell hash and gravel. The cleared clam beaches were often found along the edges of inlets and had a mix of sand, gravel, and shell hash substrate. In contrast, the nonwalled beaches we documented were primarily located at the head of small inlets, had a steeper slope, and were composed of sediment that was primarily silty sand and mud.

Near the head of the southeastern most inlet, we recorded a concentration of archaeological features including a cleared beach, a possible small root garden, a canoe run, a stone fish trap, and a shell midden with an associated artifact that is likely a net weight used for fishing. Based on the surface exposure, the shell midden reveals the use of shellfish, fish, and marine mammals. The possible root garden was situated on a small terrace in the upper intertidal and was dominated by Pacific silverweed with dispersed springbank clover. This feature was also associated with the recently identified canoe run and with one previously recorded double walled fish trap (Fig.3D). The previously unrecorded stone fish trap identified in our survey was located in the upper intertidal near the mouth of a small river and included a series of circular traps or pools that were created by clearing away rocks and boulders. 
Table 1. Our shoreline surveys at low tide, in combination with previous records, revealed a diverse range of archaeological site types within Kwakshua Channel, British Columbia, Canada.

\begin{tabular}{|c|c|c|c|c|c|c|}
\hline Site Type & $\begin{array}{l}{ }^{\dagger} \text { Total number of sites } \\
\text { or features on landscape }\end{array}$ & $\begin{array}{c}\text { Sites } \\
\text { identified in } \\
2012 \text { survey }\end{array}$ & $\begin{array}{c}\text { Sites } \\
\text { identified in } \\
2013 \text { survey }\end{array}$ & $\begin{array}{l}\text { Previously } \\
\text { recorded } \\
\text { sites }\end{array}$ & Archaeological reports & Publication \\
\hline Shell midden & 25 & 0 & 1 & 24 & $\begin{array}{l}\text { Pomeroy 1980, Hobler 1988, Stryd } \\
\text { et al. 1993, McLaren and } \\
\text { Christensen } 2014\end{array}$ & McLaren et al. 2015 \\
\hline Culturally modified tree (CMT) & 18 & 0 & 0 & 18 & $\begin{array}{l}\text { Stryd et al. 1993, McLaren and } \\
\text { Christensen } 2014\end{array}$ & \\
\hline Nonwalled clam beach & 16 & 16 & 0 & 0 & N/A & \\
\hline Clam garden & 10 & 8 & 0 & 2 & McLaren and Christensen 2014 & \\
\hline Lithic scatter & 9 & 0 & 0 & 9 & $\begin{array}{l}\text { Hobler 1988, McLaren and } \\
\text { Christensen } 2014\end{array}$ & \\
\hline Rock art & 7 & 0 & 0 & 7 & $\begin{array}{l}\text { Hobler 1988, Stryd et al. } 1993 \text {, } \\
\text { McLaren and Christensen } 2014\end{array}$ & \\
\hline Stone fish trap & 6 & 2 & 0 & 4 & McLaren and Christensen 2014 & \\
\hline Canoe run & 6 & 1 & 0 & 5 & McLaren and Christensen 2014 & \\
\hline Village/large settlement & 4 & 0 & 0 & 4 & McLaren and Christensen 2014 & McLaren et al. 2015 \\
\hline Cleared beach & 3 & 3 & 0 & 0 & N/A & \\
\hline Root garden & 1 & 0 & 1 & 0 & N/A & \\
\hline Burial/cemetery & 1 & 0 & 0 & 1 & Hobler 1988 & \\
\hline Defensive & 1 & 0 & 0 & 1 & McLaren and Christensen 2014 & \\
\hline
\end{tabular}

Fig. 3. Our shoreline survey revealed: (A) eight ancient clam gardens built along the edges of inlets with distinct rock walls between $0.5-0.8 \mathrm{~m}$ above chart datum and beach terraces landward of the wall; (B) three nonwalled but cleared clam beaches with stones moved shoreward; (C) a possible estuarine root garden with Pacific silverweed (Potentilla anserina ssp. pacifica) and dispersed springbank clover (Trifolium wormskioldii); and (D) a double walled fish trap at the mouth of a small river found in associated with the root garden, a cleared beach, circular fish traps, and a shell midden with a net fishing weight artifact. These and previously recorded archeological features in the area, including culturally modified trees, intertidal lithics, canoe runs, and 2 village sites with early components that date to 10,000 and 6000 years B.P. (McLaren et al. 2015), are all listed in Table 1. Photographs by A. Salomon (A), J. Jackley (B), N. Turner (C, an example root garden from nearby Hunter Island), and A. Groesbeck (D).
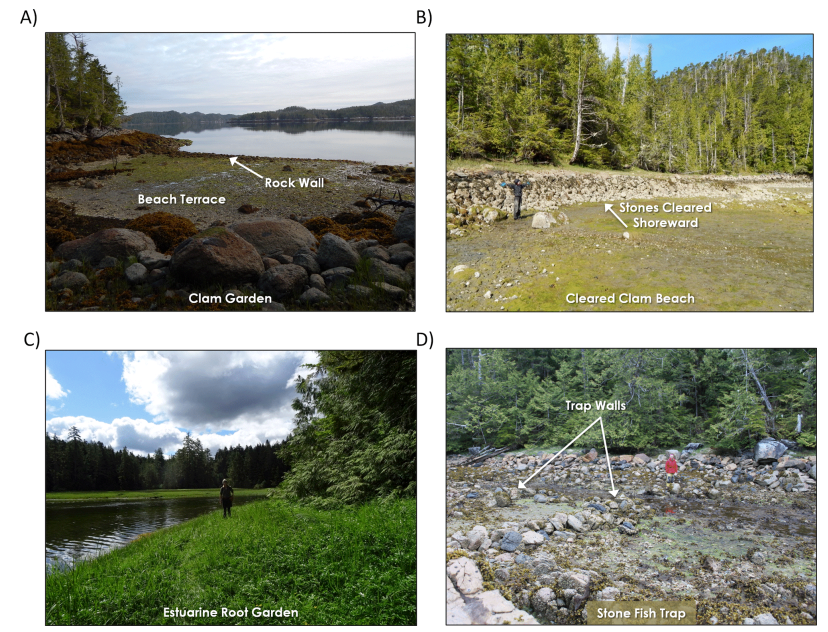

Fig. 4. Intertidal height of our 15 tidal stations where clams were surveyed from $25 \times 25 \times 25 \mathrm{~cm}$ samples at 3 ancient clam gardens (green) and 3 nonwalled clam beaches (blue) in Kwakshua Channel, British Columbia, Canada. LLWLT = lowest low water large tide.

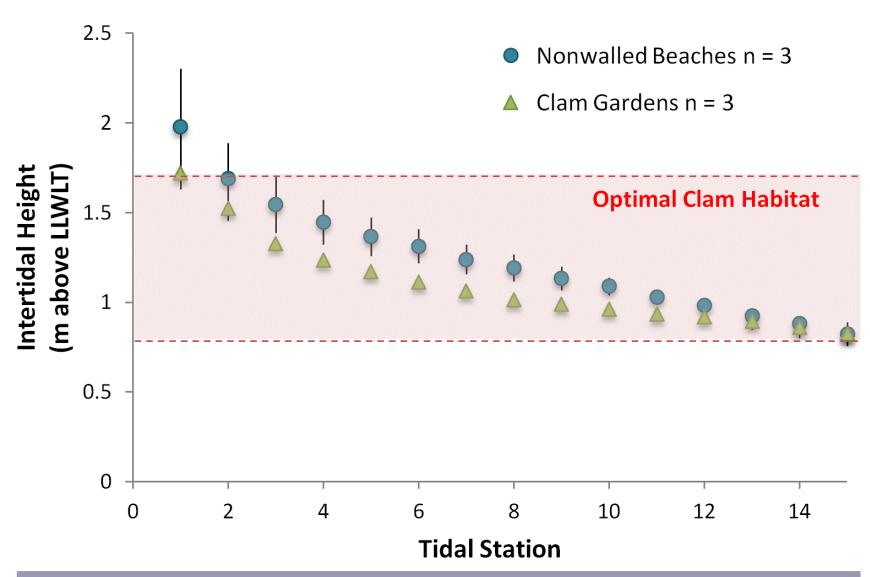

\section{Clam gardens}

Bivalve biomass, density, and community composition

Strong evidence suggests that greater butter clam biomass exists in clam gardens compared to nonwalled beaches and that butter clam biomass differed between clam gardens and nonwalled beaches as a function of tidal station (Table 2, Fig. 5A,B). Furthermore, as predicted, the effect of tidal station on butter clam biomass was mediated by the effect of beach type (Table 2; full model plus interaction term $\Delta \mathrm{AIC}_{\mathrm{c}}=0, \mathrm{w}_{\mathrm{i}}=1$ ), such that the biomass of butter clams tended to be greater in clam gardens than 
Table 2. Strength of evidence for alternative candidate models examining the effects of beach type (clam garden versus nonwalled beach) and tidal station on the biomass and density of adult butter (Saxidomus gigantea), bentnose macoma (Macoma nusata), native littleneck clam (Leukoma staminea), and total clams, in addition to clam recruits, both $<2 \mathrm{~mm}$ and $2-5 \mathrm{~mm}$. Models with parameters $(\mathrm{K})$ were compared using small-sample bias-corrected Akaike's information criterion (AIC $)_{c}$, differences in $\mathrm{AIC}_{\mathrm{c}}\left(\Delta \mathrm{AIC}_{\mathrm{c}}\right)$ and normalized Akaike weights $\left(\mathrm{W}_{\mathrm{i}}\right)$ representing the strength of evidence for model $\mathrm{i}$. All models include site as a nested, random factor, and variance structures denoted as: ${ }^{1}$ constant power variance structure, ${ }^{2}$ power variance structure, ${ }^{3}$ exponential variance structure,

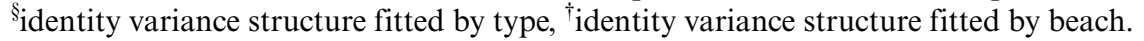

\begin{tabular}{|c|c|c|c|c|}
\hline Response and Model & $\mathrm{AIC}$ & $\triangle \mathrm{AIC}$ & $\mathrm{w}_{\mathrm{i}}$ & $\mathrm{K}$ \\
\hline \multicolumn{5}{|l|}{ Biomass of butter' } \\
\hline Type + Station + Type*Station & 1086.39 & 0 & 1 & 8 \\
\hline Type + Station & 1119.80 & 33.41 & 0 & 7 \\
\hline Station & 1133.86 & 47.47 & 0 & 6 \\
\hline Type & 1143.23 & 56.84 & 0 & 6 \\
\hline Intercept & 1180.22 & 93.83 & 0 & 5 \\
\hline \multicolumn{5}{|l|}{ Biomass of littleneck ${ }^{2}$} \\
\hline Type + Station + Type*Station & 913.23 & 0 & 0.88 & 7 \\
\hline Type & 918.12 & 4.89 & 0.08 & 5 \\
\hline Type + Station & 919.22 & 5.99 & 0.04 & 6 \\
\hline Station & 976.98 & 63.75 & 0 & 4 \\
\hline Intercept & 978.01 & 64.78 & 0 & 3 \\
\hline \multicolumn{5}{|l|}{ Biomass of macoma ${ }^{2}$} \\
\hline Type + Station & 696.00 & 0 & 0.59 & 6 \\
\hline Type + Station + Type*Station & 697.52 & 1.52 & 0.28 & 7 \\
\hline Station & 698.97 & 2.97 & 0.13 & 5 \\
\hline Type & 721.97 & 25.98 & 0 & 5 \\
\hline Intercept & 725.76 & 29.77 & 0 & 4 \\
\hline \multicolumn{5}{|l|}{ Biomass of total clams ${ }^{2}$} \\
\hline Type + Station + Type* Station & 1113.31 & 0 & 1 & 7 \\
\hline Type + Station & 1133.47 & 20.16 & 0 & 6 \\
\hline Type & 1144.64 & 31.33 & 0 & 5 \\
\hline Station & 1145.56 & 32.26 & 0 & 5 \\
\hline Intercept & 1181.30 & 67.99 & 0 & 3 \\
\hline \multicolumn{5}{|l|}{ Density of butter ${ }^{3}$} \\
\hline Intercept & 330.29 & 0.00 & 0.46 & 5 \\
\hline Type & 330.92 & 0.63 & 00.33 & 6 \\
\hline Station & 332.96 & 2.67 & 0.12 & 6 \\
\hline Type + Station & 333.60 & 3.31 & 0.09 & 7 \\
\hline Type + Station + Type* $*$ Station & 339.38 & 9.09 & 0.00 & 8 \\
\hline \multicolumn{5}{|l|}{ Density of littleneck ${ }^{\S}$} \\
\hline Intercept & 249.38 & 0.00 & 0.54 & 4 \\
\hline Type & 249.75 & 0.37 & 0.45 & 5 \\
\hline Station & 257.48 & 8.10 & 0.01 & 5 \\
\hline Type + Station & 257.90 & 8.52 & 0.01 & 6 \\
\hline \multirow{2}{*}{\multicolumn{5}{|c|}{ Density of macoma }} \\
\hline & & & & \\
\hline Intercept & 251.30 & 0.00 & 0.30 & 8 \\
\hline Station & 251.85 & 0.55 & 0.23 & 9 \\
\hline Type & 251.97 & 0.67 & 0.22 & 9 \\
\hline Type + Station & 252.63 & 1.33 & 0.16 & 10 \\
\hline Type + Station + Type*Station & 253.67 & 2.38 & 0.09 & 11 \\
\hline \multicolumn{5}{|l|}{ Density of total clams ${ }^{3}$} \\
\hline Type & 240.53 & 0.00 & 0.42 & 6 \\
\hline Station & 241.42 & 0.88 & 0.27 & 6 \\
\hline Type + Station & 241.51 & 0.98 & 0.26 & 7 \\
\hline Type + Station + Type* Station & 245.13 & 4.60 & 0.04 & 8 \\
\hline Intercept & 251.43 & 10.90 & 0.00 & 4 \\
\hline \multicolumn{5}{|l|}{ Density of clam recruits $(<2 \mathrm{~mm})$} \\
\hline Intercept & 222.67 & 0 & 0.56 & 2 \\
\hline Station & 224.54 & 1.86 & 0.22 & 3 \\
\hline Type & 225.20 & 2.53 & 0.16 & 3 \\
\hline Type + Station & 227.34 & 4.67 & 0.05 & 4 \\
\hline Type + Station + Type $*$ Station & $230 . .56$ & 7.89 & 0.01 & 5 \\
\hline \multicolumn{5}{|l|}{ Density of clam recruits $(2-5 \mathrm{~mm})$} \\
\hline Station & 291.77 & 0 & 0.42 & 3 \\
\hline Intercept & 292.19 & 0.43 & 0.34 & 2 \\
\hline Type + Station & 294.44 & 2.68 & 0.11 & 4 \\
\hline Type & 294.62 & 2.85 & 0.10 & 3 \\
\hline Type + Station + Type* $*$ Station & 297.22 & 5.45 & 0.03 & 5 \\
\hline
\end{tabular}


Fig. 5. Variation in species-specific bivalve biomass and density $( \pm S E)$ as a function of tidal station in $(A$ and $C)$ nonwalled beaches $(n=3)$ and $(B$ and $D)$ clam gardens $(n=3)$ in Kwakshua Channel, British Columbia, Canada. Unique symbols and colors represent different species of clams: Butter clam (Saxidomus gigantea), bentnose macoma (Macoma nusata), native littleneck clam (Leukoma staminea), and cockle (Clinocardium nuttallii).
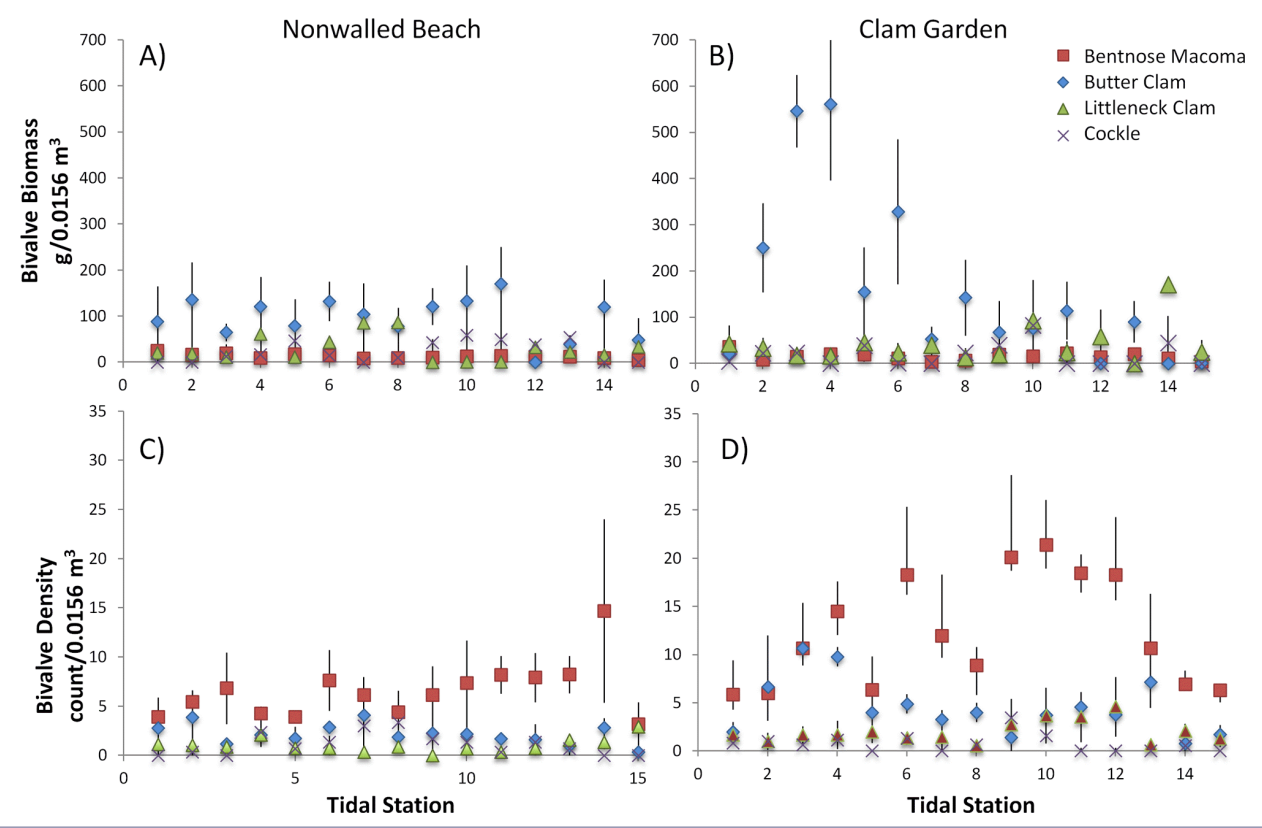

nonwalled beaches, particularly at tidal stations toward the top of the beach, where optimal clam habitat was extended. This effect was strongest at tidal stations two to six, between tidal heights of 1 to $1.5 \mathrm{~m}$. On average, butter clam biomass was 1.96 times greater in clam gardens than nonwalled beaches. These differences in biomass were driven by differences in clam sizes between clam gardens and nonwalled beaches. For example, the range in butter clam length was larger in clam gardens $(7-137 \mathrm{~mm})$ versus nonwalled beaches $(8-91 \mathrm{~mm})$. Additionally, a greater proportion of larger clams (length $>60 \mathrm{~mm}$ ) were found in clam gardens compared to nonwalled beaches.

Similarly, we found strong evidence that the biomass of native littleneck clams was greater in clam gardens than nonwalled beaches. Here too, the effect of tidal station was mediated by the effect of beach type (Table 2; full model plus interaction term $\left.\Delta \mathrm{AIC}_{\mathrm{c}}=0, \mathrm{w}_{\mathrm{i}}=0.88\right)$. Although the biomass of bentnose macoma was also driven by beach type and tidal station, there was no evidence that beach type did or did not meditate the effect of tidal station (Table 2; full model plus interaction term $\triangle \mathrm{AIC}_{\mathrm{c}}=0, \mathrm{w}_{\mathrm{i}}$ $=0.28$ ). Over all species of clams, we found more clam biomass in clam gardens than nonwalled beaches, and this effect varied with tidal station because of a reduction in clam garden beach terrace intertidal height (Table 2, Fig. 4, 5, 6).

We detected higher total clam density in clam gardens compared to nonwalled beaches, with strong evidence to suggest that there was an effect of both tidal station and beach type (Table 2, Fig. 6B). Although we observed, on average, higher densities of butter clams, native littlenecks, and macoma clams in clam gardens compared to nonwalled beaches, we found no clear evidence that beach type or tidal station affected their species-specific densities (Table 2; intercept model of no effect for each species $\mathrm{w}_{\mathrm{i}}=0.46$, 0.54, 0.30, respectively; Fig. 5C,D).

Fig. 6. Total bivalve (A) biomass and (B) density ( \pm SE) as a function of tidal station in clam gardens $(n=3)$ and nonwalled beaches $(n=3)$ in Kwakshua Channel, British Columbia, Canada.
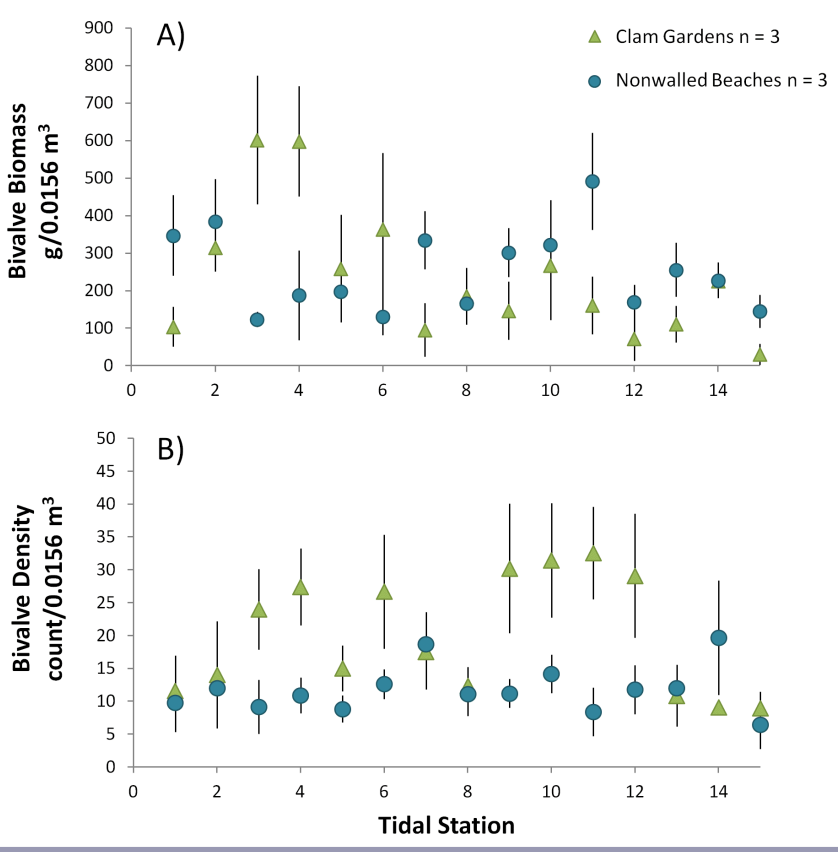
Clam community composition differed slightly between beach types. Specifically, butter, bentnose macoma, native littleneck clams, and cockles were present in the sediment of both clam gardens and nonwalled beaches. However, Baltic macoma (Macoma balthica) and the invasive littleneck clam (Venerupis philippinarum) were present only in nonwalled clam beaches.

\section{Optimal clam habitat models}

As predicted, the magnitude of biomass and density (a) of all clam species was higher in clam gardens compared to nonwalled beaches, and the standard deviation $(\sigma)$, describing the range of intertidal heights at which clams are found, was consistently lower (Table 3; Fig. 7; Fig. A2.1). Total clam density and biomass peaked at approximately the same intertidal height $\mu$ (mean) in clam gardens and nonwalled beaches (Table 3 ). Native littleneck and bentnose macoma biomass and density did not conform well to a Gaussian relationship because of higher densities found in the lower intertidal than expected. Although we did not detect an effect of beach type for bentnose macoma clam density, the parameter $a$ was higher in clam gardens relative to nonwalled beaches (Table 3 ).

\section{Bivalve recruitment}

Overall, we found high variability in the density of bivalve recruits within and between tidal stations, in both clam gardens and nonwalled beaches (Fig. 8). Although we did not detect evidence for an effect of beach type on clam recruitment (intercept model of no effect within two $\triangle \mathrm{AIC}_{\mathrm{c}}$ units of top models; Table 2), clam recruits between the sizes of $0.5-2 \mathrm{~mm}$ tended to be in greater densities, albeit more variable, in clam gardens compared to nonwalled beaches (Fig. 8A). Across both beach types, densities of 2-5 mm clam recruits were lowest at the top of the beach (tidal station 1) and highest at tidal station 11 (0.88-1.09 m intertidal height; Fig. 8B).

Table 3. Parameters for the modeled response of biomass $\left(\mathrm{g} / 0.0156 \mathrm{~m}^{3}\right)$ of butter clam (Saxidomus gigantea), bentnose macoma (Macoma spp.), native littleneck clam (Leukoma staminea), and total clam species as a function of intertidal height. Each response was predicted by modeling a gaussian curve to the data, $\mathrm{y}=\mathrm{a} * \exp \left(-0.5^{*}((\mathrm{x}-\mu) / \sigma) 2\right)$, where $\mathrm{y}=$ response, $\mathrm{x}=$ intertidal height, $\mathrm{a}=$ height, $\mu=$ mean, and $\sigma=$ standard deviation. $\mathrm{NW}=$ nonwalled, $\mathrm{CG}=$ clam gardens .

\begin{tabular}{llcccc}
\hline \hline Type & Response & $\begin{array}{c}\mathrm{a} \\
\text { (height) }\end{array}$ & $\begin{array}{c}\mu \\
\text { (mean) }\end{array}$ & $\begin{array}{c}\sigma \\
\text { (standard } \\
\text { deviation) }\end{array}$ & $\begin{array}{c}\text { SSQ (sum } \\
\text { of squares) }\end{array}$ \\
\hline NW & S. gigantea biomass & 112.54 & 1.31 & 0.57 & $375,386.44$ \\
CG & S. gigantea biomass & 521.96 & 1.32 & 0.15 & $986,214.38$ \\
NW & L. staminea biomass & 16.14 & 1.43 & 0.88 & $21,965.58$ \\
CG & L. staminea biomass & 106.66 & 0 & 0.93 & $219,956.79$ \\
NW & M. spp. biomass & 13.17 & 0 & 700.50 & 6104.26 \\
CG & M. spp. biomass & 15.13 & 1.10 & 0.39 & 1292.47 \\
NW & All spp. biomass & 141.39 & 1.35 & 0.66 & $438,020.69$ \\
CG & All spp. biomass & 504.59 & 1.31 & 0.21 & $1,409,346.45$ \\
\hline
\end{tabular}

\section{DISCUSSION}

According to our findings, ancient clam gardens on the central coast of British Columbia, Canada, have higher total clam biomass and density than nonwalled clam beaches and they are
Fig. 7. Actual (symbols) and predicted (line) biomass of (A and $\mathrm{B})$ butter clams, $(\mathrm{C}$ and $\mathrm{D})$ native littleneck clams, $(\mathrm{E}$ and $\mathrm{F})$ macoma clams, and $(\mathrm{G}$ and $\mathrm{H})$ total clams as a function of intertidal height ( $\mathrm{m}$ above LLWLT) in nonwalled beaches (blue) and clam gardens (green). Note variation in y-axes range among different bivalve species. LLWLT $=$ lowest low water large tide.

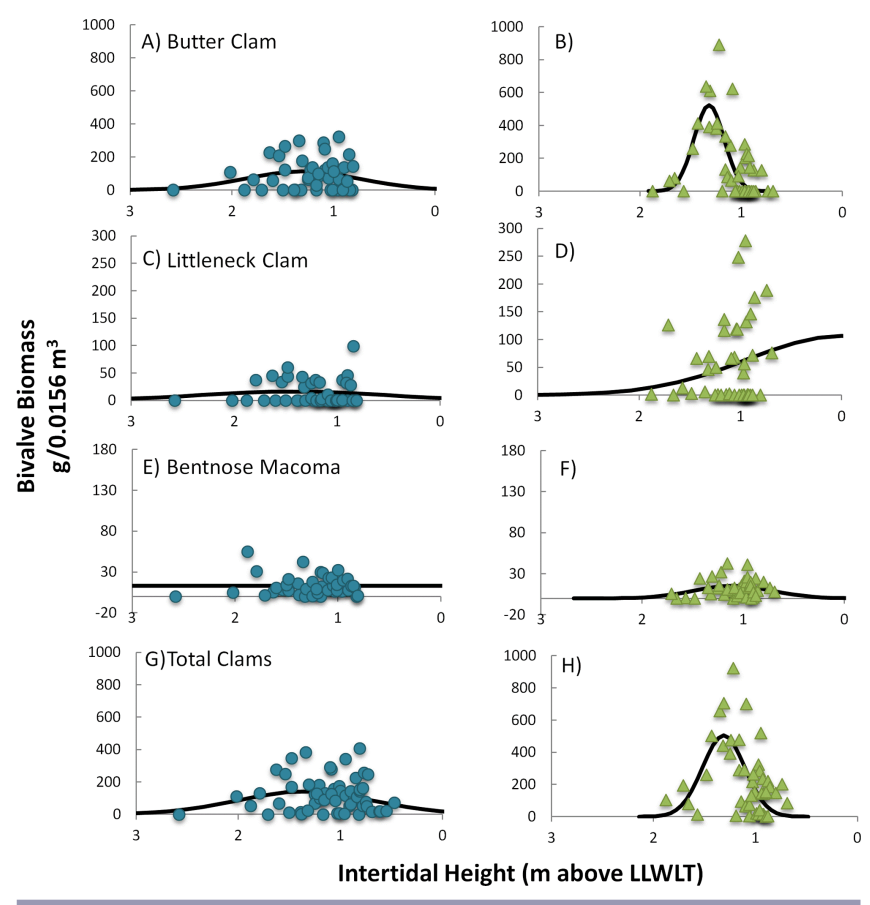

Fig. 8. Density $\left(0.0156 \mathrm{~m}^{3} \pm \mathrm{SE}\right)$ of bivalve recruits $(\mathrm{A})<2 \mathrm{~mm}$ in length and (B) $2-5 \mathrm{~mm}$ in length in clam gardens $(\mathrm{n}=3)$ and nonwalled beaches $(n=3)$ at tidal stations $1,5,11$, and 15 .
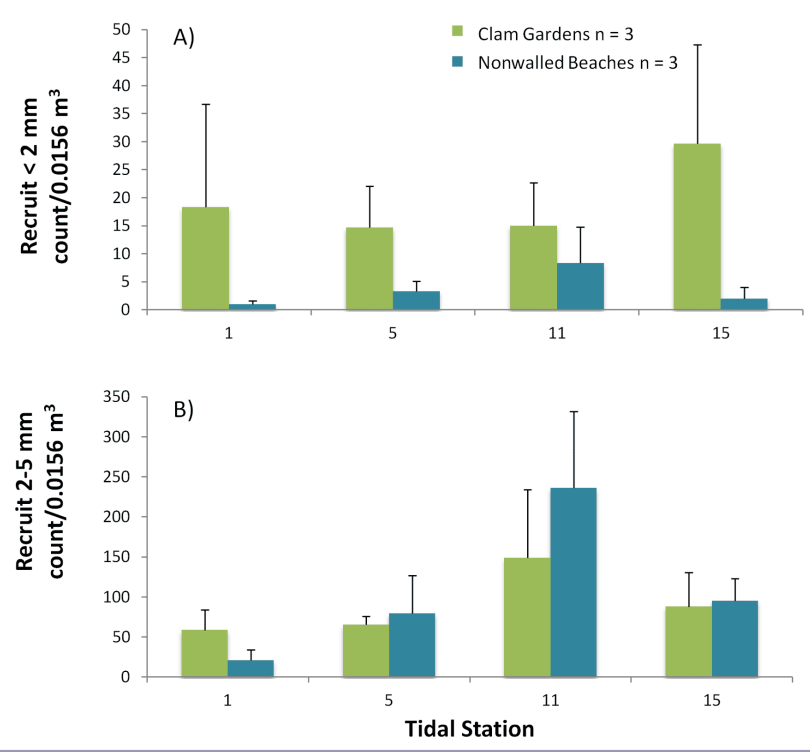
but one ancient management technology nested within a broader eco-cultural landscape. This landscape includes a diversity of resource harvesting and processing sites that could have helped ancient communities adapt to a range of external perturbations experienced in the area. Although the antiquity of many of these features has yet to be determined by radiocarbon dating, the presence and spatial distribution of resource use and a portfolio of management technologies evident across this land and seascape continuum suggests that this system was modified and managed to enhance food production, access, and security over millennia (Table 1). Clam gardens would have been an important component to this diverse and complex coastal resource management system.

\section{Enhanced bivalve biomass and density in clam gardens}

Strong evidence suggests that clam gardens in the Kwakshua Channel have greater total bivalve biomass and density when compared to nonwalled beaches (Fig. 5, 6). This was particularly the case for butter clams that had 1.96 times the biomass and 2.44 times the density in clam gardens relative to unmodified beaches. Clam species have a specific range of intertidal heights at which they are found (Quayle and Bourne 1972), and a flatter beach within this range would increase the area of optimal habitat for certain species (Fig. 2A,B). Consequently, the enhanced clam biomass within clam gardens that we report, most notably at upper tidal stations, is likely attributable to the increase in optimal clam habitat and thus ideal growing conditions (i.e., optimal moisture and temperature) due to their reduced beach slope (Table 2; Fig. 4). These findings are consistent with our predictions and with previous research on clam gardens conducted elsewhere in British Columbia, on Quadra Island, $300 \mathrm{~km}$ south of Kwakshua Channel (Groesbeck et al. 2014).

Mechanisms in addition to the modification of beach slope may magnify the densities of butter clams detected in clam gardens compared to nonwalled beaches. We observed a difference in substrate type and quality between beach types where clam garden sediment was primarily composed of shell hash and gravel whereas nonwalled beach sediment was primarily silty sand and mud. The addition of shell hash and gravel to clam gardens has the effect of modifying the substrate size in a beach, which can influence clam recruitment, growth, and survival (Paterson and Neil 1997). The difference in substrate between clam gardens and nonwalled beaches may also explain the differential presence of Baltic macoma and invasive littleneck clams, which were only found in unmodified, nonwalled beaches, possibly because of the siltier and muddier conditions (Huxham and Richards 2003).

\section{Larval clam delivery and recruitment}

Although we predicted that clam gardens would experience higher rates of larval clam recruitment because of an expanded range of optimal clam growing conditions (e.g., moisture, temperature) and the presence of shell hash substrate known to induce the settlement of pelagic larval clams (e.g., Butman et al. 1988, Green et al. 2013), we found little evidence in support of this hypothesis, likely because of the high variability in bivalve recruits we found within and between tidal stations in clam gardens and nonwalled beaches. However, consistent with our prediction, we did find that the number of clam recruits between the sizes of $0.5-2 \mathrm{~mm}$ tended to be higher, albeit more variable, in clam gardens compared to nonwalled beaches (Fig. 8A). A greater number of samples of clam recruits, across both beach types and over the spring and summer spawning seasons, in addition to the enumeration of microscopic clam recruits smaller than $0.5 \mathrm{~mm}$, would vastly improve our ability to assess the effect of clam gardens on clam recruitment. Nonetheless, the trend in our data suggests that the alteration of postsettlement processes that influence clam recruit growth may contribute to the elevated adult clam biomass and density in clam gardens. These postsettlement processes could include physical disturbance, oxygen limitation, desiccation, food delivery, and predation (Rodnick and $\mathrm{Li}$ 1983, Hunt and Scheibling 1997). For example, optimal substrate composition for native littleneck clams is a mix of coarse sand, gravel, and shell, which was present at the clam gardens we sampled. It is possible that in nonwalled beaches, larval recruits experience higher mortality caused by a higher likelihood of being buried, or smothered in less stable substrates such as fine silts (Peterson 1985, Quayle and Newkirk 1989, Toba et al. 1992). Additionally, clam gardens may retain water for longer periods of time because of their reduced slope. In such conditions, larvae may experience less desiccation and more consistent temperatures, reducing the thermal stress associated with variable temperatures in both the winter (i.e., when clams are prone to freezing events) and summer (i.e., when high midday temperatures coinciding with the low tide might exceed thermal tolerances of some clam species). Increased submersion times and water retention in clam gardens compared to nonwalled beaches may also increase the delivery, availability, and thus consumption of phytoplankton. To test among competing mechanisms that promote increased clam growth and survivorship in clam gardens, future experimental transplants of clam recruits in clam gardens and nonwalled beaches while manipulating and measuring factors such as predator access, water moisture, temperature, $\mathrm{pH}$, amount of shell hash, and pore water, would help resolve what factors drive the variation in beach type we have reported here.

In our study, we measured larval recruitment by assessing the density of clam recruits between 0.5-5 mm. Most clams in British Columbia spawn as early as April or May (Quayle and Bourne 1972), and our investigation took place in late May. The larval period for native littleneck clams is three weeks in length, and newly settled recruits ( $<0.5 \mathrm{~mm}$ in length) were noted in some of our samples, so it is likely that a settlement event(s) occurred before our study. Previous work has shown that juvenile clams, but not adults, experience higher growth rates in clam gardens (Groesbeck et al. 2014), and it is possible that clam gardens may influence the growth of clam recruits as well. Moreover, if clam gardens are constructed in areas that would not otherwise support clam populations (e.g., steep and rocky shorelines), there may be an overall increase in survival of larval recruits where ordinarily it would be low or nonexistent.

\section{Landscape modification, management, and biological productivity}

There is increasing recognition that indigenous people in North America developed a range of land- and sea-scape management practices to increase the availability, abundance, and diversity of resources (e.g., Hunn 1990, Blackburn and Anderson 1993, Boyd 1999, Anderson 2005, Berkes and Davidson-Hunt 2006, Fowler and Lepofsky 2011, Turner 2014). Although much of this work has focused on terrestrial management systems, the clam gardens documented in this study add to a growing literature documenting 
traditional marine management systems and the long-term effects these practices can have on species and ecosystems (e.g., CostaPierce 1987, Hunn et al. 2003, Langdon 2006, Lepofsky and Caldwell 2013, Lepofsky et al. 2015, Thornton 2015). Although evidence for past resource management can be somewhat elusive (Lepofsky and Lertzman 2008), many management practices do leave an imprint on the landscape, resulting in a mix of archaeological site types. The abundance and diversity of sites within Kwakshua Channel is reflective of the range of past landscape modifications as well as the natural diversity of ecosystems in the area.

Our study provides a focused examination of just one of the many ways past peoples modified a diverse coastal landscape to enhance resource production and access. By reducing the beach slope, clam gardens in Kwakshua Channel expanded optimal clam habitat to increase both the abundance and biomass of clams. Our shoreline survey indicated that, in addition to clam gardens, shellfish may have been available in other locations (e.g., cleared beaches, nonwalled beaches), although in less abundance and possibly of smaller sizes. The diversity in the locations of these harvesting areas may have provided relatively consistent access to shellfish over time and the availability of other marine and terrestrial resources within the channel could have reduced the risk of food insecurity when shellfish were less available or possibly contaminated by natural toxins in some spring and summer phytoplankton blooms. Furthermore, these management features within Kwakshua Channel could have been connected to broader social networks that shared resources across ecologically diverse landscapes to help mitigate resource scarcity (e.g., Suttles 1987, Lepofsky et al. 2005b).

Previous archaeological excavation and our shoreline survey suggest that people have gathered and processed resources and lived on the landscape for millennia (Table 1). Along the north end of Kwakshua Channel, two village sites provide evidence of long-term human occupation and use (McLaren et al. 2015). One site revealed early cultural components that were radiocarbon dated to at least 90000-10,000 years B.P. (McLaren and Christensen 2014) and a second site suggests continuous occupation beginning around 6000 years B.P. (McLaren et al. 2015). The ages of other features on the landscape are currently unknown, but clam gardens (Lepofsky et al. 2015) and fish traps (Pomeroy 1980, Moss and Erlandson 1998) located elsewhere on the northwest coast have been dated to the late Holocene. However, given that sea levels in this region have been relatively stable since the early Holocene (McLaren et al. 2014), it is possible that the features in Kwakshua Channel could be as old, if not older, than those documented elsewhere in British Columbia and thus could provide insight to early marine management on North America's Pacific northwest coast.

The long-term use and occupation of sites in Kwakshua Channel provide evidence of a deep connection to and investment in place. The relative stability of the shoreline through time in conjunction with deeply held traditions of land ownership by specific chiefs and families allowed for the accumulation of large and deep archaeological deposits that range from the early to late Holocene (McLaren et al. 2015). Although the age of many of the sites and features is unknown, it is clear that the landscape was imprinted by a diversity of management technologies and strategies and it is likely that together they represent many generations of use and management.

The archaeological record reflects the use of both marine and terrestrial ecosystems ranging from the low intertidal to the surrounding hillsides. The majority of the recorded sites and features are located in the intertidal or near the shoreline (McLaren and Christensen 2014), reflecting the importance of marine resources. However, terrestrial resources would also have been essential as they provided food, construction material, fibre, and medicine for past communities (Turner 2014). Although limited, faunal analyses from shell midden sites within and near Kwakshua Channel reveal that a range of taxa were processed, including fish, shellfish, terrestrial and sea mammals, and birds (Stryd et al. 1993, McLaren and Christensen 2014). The presence of a possible root garden along the shoreline suggests that clover and silverweed roots were cultivated and harvested. These highly prized foods were important sources of carbohydrates and were often used as gifts in potlatch ceremonies (Turner and Kuhnlein 1987, Turner et al. 2013). The number of culturally modified tree (CMT) sites in the hillsides above the channel provides evidence of the use of red cedar for the collection of bark, boards, planks, and kindling, Sitka spruce for cambium and pitch collection, and western hemlock for cambium collection (Stryd et al. 1993, White 2006, McLaren and Christensen 2014).

The diversity of technologies and strategies in Kwakshua Channel could have provided alternative harvesting opportunities when key resources were less abundant or unavailable. On the central coast, people relied primarily on resources located within the immediate vicinity of village sites (Cannon et al. 2008, 2011, Cannon and Burchell 2009). The variability of resources through time and across space (Suttles 1987, Ames and Maschner 1999, Cannon et al. 2011) would thus necessitate the development of multiple subsistence strategies. Therefore, the diversity of technologies dispersed across this landscape in multiple locations and numbers would have provided past communities with options in response to change.

\section{Resilience, diversity, and northwest coast sustainability}

Ethnographic sources and traditional knowledge suggest that indigenous peoples of the northwest coast of British Columbia had territorial governance systems and complex protocols that delineated access rights to land and seascapes as a means to conserve and manage most resources (Olson 1955, Hilton 1990, Harkin 1997, Jones 2002, Turner et al. 2005, Trosper 2009, Powell 2012, Salomon et al. 2014). Proprietorship of these territories was designated through a system of family-based clans, each with their own designated access areas containing seasonal fishing and hunting sites, cultivated gardens, and berry picking and tending sites, which in turn produced food, trade goods, medicines, and other important resources (Turner et al. 2005, Turner 2014). Clam gardens and clam beaches were similarly owned by specific families, and harvests were controlled by family heads (Lepofsky et al. 2015).

On the central coast, traditional management among the Heiltsuk indicate that systems of territoriality, ownership, and governance have been in place for generations and included many strategies and practices that supported long-term human interaction and use of specific resources (Hilton 1990, Harkin 1997, Jones 2002, Powell 2012, Housty et al. 2014, Gauvreau 2015; HLUP, undated 
living document). Rules and regulations, including restricted access to harvesting locations (Powell 2012), limits on the timing and methods of harvesting (Jones 2002), and intentional disuse of areas to allow for recovery (Housty et al. 2014) helped to ensure that resources were not overexploited. Although harvesting locations and resources were strictly regulated (Hilton 1990, Harkin 1997), permission to access resources could be granted upon request and elaborate winter ceremonies, such as the potlatch, facilitated the exchange of resources (Harkin 1997). These public exchanges served, in part, to demonstrate successful resource and landscape stewardship (Powell 2012) and reinforced individual and family status and rank (Hilton 1990).

Territorial access rights and rules governing the behavior of chiefs created a system of governance over common pool fisheries resources that would have conferred resilience to societies on the northwest coast for millennia (Trosper 2009). Specifically, proprietorship over territories was contingent on maintaining the productivity of a territory's resources for future generations (Turner and Jones 2000, Trosper 2009, Turner 2014). Clam gardens would have been one means by which to accomplish this. Moreover, chiefs needed to publicly demonstrate the continued productivity of resources (Turner 2014), otherwise their effectiveness as leaders could be called into question (Turner and Jones 2000, Trosper 2009). This rule created an important feedback that provided strong incentive for learning how to manage for continued use (Berkes and Turner 2006, Trosper 2009). Finally, the protocol of reciprocity, held by many coastal First Nations in British Columbia, provided additional incentives for sustainable management (Turner et al. 2005, Turner 2014). It afforded social insurance against misfortune, such that neighbouring clans could be asked for support when resources were low or management failed, knowing that such support would be reciprocated if needed in the future. Furthermore, the sharing and exchange of a territory's net returns reduces competition among resource users and incentive to overharvest, thereby providing a solution to the tragedy of the commons (Trosper 2009). The enforcement of reciprocity was made legal via the potlatch system, a public governance system among coastal First Nations whose ubiquity implies its benefits (Barnett 1938, Suttles 1960, Drucker 1965). Consequently, in addition to the structural technologies that enhanced resource production that we have documented (Table 1; Fig. 3), ancient marine tenure systems and governance protocols founded in reciprocity were likely used to conserve and manage most coastal resources.

Together, the diversity of ecosystems, available resources, resource locations, harvesting technologies, and governance protocols may have constituted a portfolio of resource use options and management strategies. A diverse resource use and management portfolio would offer an adaptive strategy to cope with fluctuating resources by reducing overall resource variability and risk of overexploitation, thereby conferring socioeconomic resilience to external perturbations through complementary and/or redundant use and management technologies (Figge 2004, Schindler et al. 2010).

We provide empirical evidence that clam gardens are but one technology within a variety of other management technologies and strategies (Table 1; Fig. 3) aimed at maintaining and/or increasing the productivity of coastal resources. These sites and features are the physical imprint of generations of human decisions and actions around the use and management of coastal ecosystems and resources. The diversity of these technologies enhances social-ecological resilience in terms of variety (i.e., how many of each feature), disparity (i.e., how different the features are from each other) and redundancy, because it provides options for responding to change and disturbance (Biggs et al. 2012). Together these management strategies facilitate the continued learning and adaptation of systems through time by connecting daily human actions and decisions with long-term effects on the environment (Berkes and Turner 2006).

\section{CONCLUSION}

We provide evidence that clam gardens in Kwakshua Channel on the central coast of B.C. increased clam biomass and density and were used in concert with a suite of other harvesting and processing methods to ensure the longevity of food security. Although the features may not have been tended in the more recent past, or for many generations, they maintain a legacy of increased shellfish productivity today, suggesting that clam gardens provided a reliable source of food for past populations through time. The persistence of clam gardens and their continued ecological effects, in addition to the diversity of eco-cultural features and structural legacies that remain on the land and seascape today, offer clues to past resource management regimes. They suggest that these features were likely part of a diverse system of management strategies used to confer resilience to ancient coastal communities by offering a portfolio of use and management options. With the integration of additional data sources (e.g., oral history, ethnography, etc.), our data can be used to better understand the social systems that directed the use and maintenance of these features and provide broader insight to resource management systems on the northwest coast.

Responses to this article can be read online at: http://www.ecologyandsociety.org/issues/responses. $\mathrm{php} / 8747$

\section{Acknowledgments:}

We thank A. Groesbeck, D. Lawson, M. Shallard, C. Kelly, J. Brown, and T. Bennington for conducting pilot clam surveys in 2012, and L. Honka, Z. Koehn, N. Bouevitch, J. Bhattacharyya, and V. Neal for field assistance in 2013. Thank you to M. Jones, P. Gibeau, and A. Cooper for statistical assistance. E. White and J. Carpenter provided valuable cultural guidance on this research and comments on this manuscript. D. McLaren, J. Stafford, J. Maxwell, E. White, D. Fedje, A. Vickers, J. Vickers, J. Cohen, D. Lepofsky, and $Q$. Mackie provided important local and regional archaeological and anthropological context. This research was a product of a graduate class on the resilience of social-ecological systems conducted in collaboration with the Hakai Institute, the Heiltsuk Integrated Resource Management Department, and the Wuikinuxv Stewardship Office. Funding was provided by the Tula Foundation and a Simon Fraser University Collaborative Teaching award to A. K. Salomon. 


\section{LITERATURE CITED}

Ames, K. M., and H. D. G. Maschner. 1999. Peoples of the northwest coast: their archaeology and prehistory. Thames and Hudson, London, UK.

Anderson, K. 2005. Tending the wild: Native American knowledge and the management of California's natural resources. University of California Press, Berkeley, California, USA.

Barnett, H. G. 1938. The nature of the potlatch. American Anthropologist 40(3):349-358. http://dx.doi.org/10.1525/ aa.1938.40.3.02a00010

Berkes, F. 2012. Sacred ecology: traditional ecological knowledge and resource management. Third edition. Routledge, New York, New York, USA.

Berkes, F., J. Colding, and C. Folke. 2000. Rediscovery of traditional ecological knowledge as adaptive management. Ecological Applications 10(5):1251-1262. http://dx.doi. org/10.1890/1051-0761(2000)010[1251:roteka]2.0.co;2

Berkes, F., and I. J. Davidson-Hunt. 2006. Biodiversity, traditional management systems, and cultural landscapes: examples from the boreal forest of Canada. International Social Science Journal 58 (187):35-47. http://dx.doi.org/10.1111/j.1468-2451.2006.00605.x

Berkes, F., and C. Folke. 2003. Navigating social and ecological systems: building resilience for complexity and change. Cambridge University Press, Cambridge, UK.

Berkes, F., and N. J. Turner. 2006. Knowledge, learning and the evolution of conservation practice for social-ecological system resilience. Human Ecology 34(4):479-494. http://dx.doi. org/10.1007/s10745-006-9008-2

Biggs, R., M. Schlüter, D. Biggs, E. L. Bohensky, S. BurnSilver, G. Cundill, V. Dakos, T. M. Daw, L. S. Evans, K. Kotschy, A. M. Leitch, C. Meek, A. Quinlan, C. Raudsepp-Hearne, M. D. Robards, M. L. Schoon, L. Schultz, and P. C. West. 2012. Toward principles for enhancing the resilience of ecosystem services. Annual Review of Environment and Resources 37:421-448. http:// dx.doi.org/10.1146/annurev-environ-051211-123836

Blackburn, T. C., and K. Anderson. 1993. Before the wilderness: environmental management by Native Californians. Ballena, Menlo Park, California, USA.

Boyd, R. T. 1999. Indians, fire, and the land in the Pacific Northwest. Oregon State University Press, Corvallis, Oregon, USA.

Brown, F., and Y. K. Brown. 2009. Staying the course, staying alive: coastal First Nations fundamental truths: biodiversity, stewardship, and sustainability. Biodiversity, B.C., Victoria, British Columbia, Canada. [online] URL: http://www. biodiversitybc.org/assets/Default/BBC Staying the Course Web. pdf

Burchell, M., A. Cannon, N. Hallmann, H. P. Schwarcz, and B. R. Schöne. 2013. Inter-site variability in the season of shellfish collection on the central coast of British Columbia. Journal of Archaeological Science 40:626-636. http://dx.doi.org/10.1016/j. jas.2012.07.002

Burnham, K. P., and D. R. Anderson. 2002. Model selection and multimodal inference: a practical information-theoretic approach. Second edition. Springer, New York, New York, USA.
Butman, C. A., J. P. Grassle, and C. M. Webb. 1988. Substrate choices made by marine larvae settling in still water and in a flume flow. Nature 333(6175):771-773. http://dx.doi.org/10.1038/333771a0

Caldwell, M. E., D. Lepofsky, G. Combes, M. Washington, J. R. Welch, and J. R. Harper. 2012. A bird's eye view of northern coast Salish intertidal resource management features, southern British Columbia, Canada. Journal of Island and Coastal Archaeology 7:219-233. http://dx.doi.org/10.1080/15564894.2011.586089

Cannon, A. 1991. The economic prehistory of Namu: patterns in vertebrate fauna. Publication 19. Archaeology Press, Simon Fraser University, Burnaby, British Columbia, Canada.

Cannon, A. 2000. Assessing variability in northwest coast salmon and herring fisheries: bucket-auger sampling of shell midden sites on the central coast of British Columbia. Journal of Archaeological Science 27:725-737. http://dx.doi.org/10.1006/ jasc. 1999.0498

Cannon, A., and M. Burchell. 2009. Clam growth-stage profiles as a measure of harvest intensity and resource management on the central coast of British Columbia. Journal of Archaeological Science 36:1050-1060. http://dx.doi.org/10.1016/j.jas.2008.12.007

Cannon, A., M. Burchell, and R. Bathurst. 2008. Trends and strategies in shellfish gathering on the Pacific northwest coast of North America. Pages 7-22 in A. Antczak and R. Cipriani, editors. Early human impact on megamolluscs. British Archaeological Reports International Series, Vol. 1865. Oxbow Books, Oxford, UK.

Cannon, A., and D. Y. Yang. 2006. Early storage and sedentism on the Pacific northwest coast: ancient DNA analysis of remains from Namu, British Columbia. American Antiquity 71 (1):123-140. http://dx.doi.org/10.2307/40035324

Cannon, A., D. Yang, and C. Speller. 2011. Site-specific salmon fisheries on the central coast of British Columbia. Pages 57-74 in M. Moss and A. Cannon, editors. The archaeology of North Pacific fisheries. University of Alaska Press, Fairbanks, Alaska, USA.

Carlson, R. L. 1979. The early period on the central coast of British Columbia. Canadian Journal of Archaeology 3:211-228.

Carlson, R. 1996. Early Namu. Pages 83-102 in R. L. Carlson and L. Dalla Bona, editors. Early human occupation in British Columbia. University of British Columbia Press, Vancouver, British Columbia, Canada.

Carpenter, S. R., and L. H. Gunderson. 2001. Coping with collapse: ecological and social dynamics in ecosystem management. BioScience 51:451-457. http://dx.doi.org/10.1641/0006-3568 (2001)051[0451:CWCEAS]2.0.CO;2

Costa-Pierce, B. A. 1987. Aquaculture in ancient Hawaii. Bioscience 37(5):320-331. http://dx.doi.org/10.2307/1310688

Deur, D. 2005. Tending the garden, making the soil: northwest coast estuarine gardens as engineered environments. Pages 296-327 in D. E. Deur and N. J. Turner, editors. Keeping it living: traditions of plant use and cultivation on the northwest coast of North America. University of Washington Press, Seattle, Washington, USA. 
Deur, D., A. Dick (Kwaxsistalla), K. Recalma-Clutesi (Ogwi'low' qwa), and N. J. Turner. 2015. Kwakwaka'wakw "clam gardens": motive and agency in traditional northwest coast mariculture. Human Ecology 43(2):201-212. http://dx.doi.org/10.1007/ $\underline{\text { s10745-015-9743-3 }}$

Deur, D. E., and N. J. Turner, editors. 2005. Keeping it living: traditions of plant use and cultivation on the northwest coast of North America. University of Washington Press, Seattle, Washington, USA.

Drucker, P. 1965. Cultures of the North Pacific coast. Chandler, New York, New York, USA.

Figge, F. 2004. Bio-folio: applying portfolio theory to biodiversity. Biodiversity and Conservation 13(4):827-849. http://dx.doi. org/10.1023/b:bioc. 0000011729.93889 .34

Folke, C. 2006. Resilience: the emergence of a perspective for social-ecological systems analyses. Global Environmental Change 16:253-267. http://dx.doi.org/10.1016/j.gloenvcha.2006.04.002

Folke, C., S. Carpenter, B. Walker, M. Scheffer, T. Elmqvist, L. Gunderson, and C. S. Holling. 2004. Regime shifts, resilience, and biodiversity in ecosystem management. Annual Review of Ecology, Evolution, and Systematics 35:557-581. http://dx.doi. org/10.1146/annurev.ecolsys.35.021103.105711

Folke, C., T. Hahn, P. Olsson, and J. Norberg. 2005. Adaptive governance of social-ecological systems. Annual Review of Environment and Resources 30:441-473. http://dx.doi.org/10.1146/ annurev.energy.30.050504.144511

Folke, C., C. S. Holling, and C. Perrings. 1996. Biological diversity, ecosystems, and the human scale. Ecological Adaptations 6 (4):1018-1024. http://dx.doi.org/10.2307/2269584

Fowler, C. S., and D. Lepofsky. 2011. Traditional resource and environmental management. Pages 285-304 in E. N. Anderson, D. Pearsall, E. S. Hunn, and N. J. Turner, editors. Ethnobiology. Wiley-Blackwell, Hoboken, New Jersey, USA. http://dx.doi. org/10.1002/9781118015872.ch17

Gauvreau, A. 2015. "Everything revolves around the herring": the Heiltsuk-herring relationship through time. Thesis. School of Resource and Environmental Management, Simon Fraser University, Burnaby, British Columbia, Canada. [online] URL: http://rem-main.rem.sfu.ca/theses/GauvreauAlisha_2015_MRM619. pdf

Groesbeck, A. S., K. Rowell, D. Lepofsky, and A. K. Salomon. 2014. Ancient clam gardens increased shellfish production: adaptive strategies from the past can inform food security today. PLoS ONE 9(3):e91235-e91235. http://dx.doi.org/10.1371/ journal.pone.0091235

Green, M. A., G. G. Waldbusser, L. Hubazc, E. Cathcart, and J. Hall. 2013. Carbonate mineral saturation state as the recruitment cue for settling bivalves in marine muds. Estuaries and Coasts 36 (1):18-27. http://dx.doi.org/10.1007/s12237-012-9549-0

Harkin, M. E. 1997. The Heiltsuks: dialogues of culture and history on the northwest coast. University of Nebraska Press, Lincoln, Nebraska, USA.
Harper, J. R. 2007. Clam garden field inventory. COBI Project 06-07. Coastal and Ocean Resources, Sidney, British Columbia, Canada.

Harper, J. R., J. Haggarty, and M. C. Morris. 1995. Broughton Archipelago clam terrace survey: final report. Land Use Coordination Office, British Columbia Ministry of Government Services, Victoria, British Columbia, Canada. [online] URL: http://aquaticcommons.org/1129/

Harper, J. R., and M. C. Morris. 2004. Quadra Island clam garden survey. Coastal and Ocean Resources, Sidney, British Columbia, Canada.

Heiltsuk Land Use Plan (HLUP). [Undated living document]. Qnqńs sásm入áts 7ń7ats: for our children's tomorrows. Heiltsuk Tribal Council, Heiltsuk Yimas Council, Bella Bella, British Columbia, Canada. [online] URL: http://www.firstnations.de/ media/04-1-land-use-plan.pdf

Hester, J. J., and S. M. Nelson. 1978. Studies in Bella Bella prehistory. Publication 5. Department of Archaeology, Simon Fraser University, Burnaby, British Columbia, Canada.

Hilton, S. 1990. Haihais, Bella Bella, and Oowekeeno. Pages 312-322 in W. Suttles, editor. Handbook of North American Indians: volume 7: northwest coast. Smithsonian Institution, Washington, D.C., USA.

Hobler, P. M. 1988. Archaeological survey in the Hakai recreation area. Archaeology Branch, Vancouver, British Columbia, Canada.

Holling, C. S. 1973. Resilience and stability of ecological systems. Annual Review of Ecology, Evolution, and Systematics 4:1-23. http://dx.doi.org/10.1146/annurev.es.04.110173.000245

Housty, W. G., A. Noson, G. W. Scoville, J. Boulanger, R. M. Jeo, C. T. Darimont, and C. E. Filardi. 2014. Grizzly bear monitoring by the Heiltsuk people as a crucible for First Nation conservation practice. Ecology and Society 19(2):70. http://dx.doi.org/10.5751/ es-06668-190270

Hunn, E. S. 1990. Nch'i-wána, "the big river": mid-Columbia Indians and their land. University of Washington Press, Seattle, Washington, USA.

Hunn, E. S., D. R. Johnson, P. N. Russell, and T. F. Thornton. 2003. Huna Tlingit traditional environmental knowledge, conservation, and the management of a "wilderness" park. Current Anthropology 44 (Suppl.):S79-S103. http://dx.doi. org/10.1086/377666

Hunt, H. L., and R. E. Scheibling. 1997. Role of early postsettlement mortality in recruitment of benthic marine invertebrates marine. Marine Ecology Progress Series 155:269-301. http://dx.doi.org/10.3354/meps155269

Huxham, M., and M. Richards. 2003. Can postlarval bivalves select sediment type during settlement? A field test with Macoma balthica (L.) and Cerastoderma edule (L.). Journal of Experimental Marine Biology and Ecology 288:279-293. http://dx. doi.org/10.1016/S0022-0981(03)00023-6

Jones, J. T. 2002. We looked after all the salmon streams: traditional Heiltsuk cultural stewardship of salmon and salmon streams. 
Thesis. School of Environmental Studies, University of Victoria, Victoria, British Columbia, Canada.

Kii'iljuus Wilson, B., and K. J. Luu Gaahlandaay Borserio. 2011. Gam luu tllgaay aa k'iixa Gang ga; there is no land strange. Pages 187-196 in S. Steedman, Jisgang, and N. Collison, editors. That which makes us Haida: the Haida language book. Haida Gwaii Museum, Skidegate, British Columbia, Canada.

Langdon, S. J. 2006. Traditional knowledge and harvesting of salmon by Huna and Hinyaa Tlingit: final report. Study No. 02-104. U.S. Fish and Wildlife Service, Office of Subsistence Management, Fisheries Resource Monitoring Program, Anchorage, Alaska, USA. [online] URL: http://www.seawead. org/images_documents/documents/KCF/LangTlinSalTEK06.pdf

Lepofksy, D., and M. Caldwell. 2013. Indigenous marine resource management on the northwest coast of North America. Ecological Processes 2:1-12. http://dx.doi.org/10.1186/2192-1709-2-12

Lepofsky, D., D. Hallett, K. Lertzman, R. Mathewes, A. McHalsie, and K. Washbrook. 2005a. Documenting precontact plant management on the northwest coast: an example of prescribed burning in the central and upper Fraser Valley, British Columbia. Pages 218-239 in D. Deur and N. Turner, editors. Keeping it living: traditions of plant use and cultivation on the northwest coast of North America. University of Washington Press, Seattle, Washington, USA.

Lepofsky, D., and K. Lertzman. 2008. Documenting ancient plant management in the northwest of North America. Botany 86:129-145. http://dx.doi.org/10.1139/B07-094

Lepofsky, D. K. Lertzman, D. Hallett, and R. Mathewes. $2005 b$. Climate change and culture change on the southern coast of British Columbia 2400-1200 cal. B.P: an hypothesis. American Antiquity 70(2):267-293. http://dx.doi.org/10.2307/40035704

Lepofsky, D., N. F. Smith, N. Cardinal, J. Harper, M. Morris, Gitla (E. White), R. Bouchard, D. I. D. Kennedy, A. K. Salomon, M. Puckett, K. Rowell, and E. M. McLay. 2015. Ancient shellfish mariculture on the northwest coast of North America. American Antiquity 80:(2):236-259. http://dx.doi.org/10.7183/0002-7316.80.2.236

Low, B., E. Ostrom, C. Simon, and J. Wilson. 2003. Redundancy and diversity: do they influence optimal management? Pages 83-114 in F. Berkes, J. Colding, and C. Folke, editors. Navigating social and ecological systems: building resilience for complexity and change. Cambridge University Press, Cambridge, UK. http:// dx.doi.org/10.1017/cbo9780511541957.007

McLaren, D., and T. Christensen. 2014. Report for the Hakai ancient landscapes archaeology project: 2011 and 2012 field seasons. Archaeology Branch, Vancouver, British Columbia, Canada.

McLaren, D., D. Fedje, M. B. Hay, Q. Mackie, I. J. Walker, D. H. Shugar, J. B. R. Eamer, O. B. Lian, and C. Neudorf. 2014. A postglacial sea level hinge on the central Pacific coast of Canada. Quaternary Science Reviews 97:148-169. http://dx.doi.org/10.1016/ j.quascirev.2014.05.023

McLaren, D., F. Rahemtulla, Gitla (E. White), and D. Fedje. 2015. Perogatives, sea level, and the strength of persistent places: archaeological evidence for long-term occupation of the central coast of British Columbia. B. C. Studies 187:155-193.
Meidinger, D. V., and J. Pojar, editors. 1991. Ecosystems of British Columbia. Research Branch, Ministry of Forests and Lands, Victoria, British Columbia, Canada. [online] URL: https://www. for.gov.bc.ca/hfd/pubs/Docs/Srs/Srs06.htm

Moss, M. L., and J. M. Erlandson. 1998. A comparative chronology of northwest coast fishing features. Pages 180-198 in K. Bernick, editor. Hidden dimensions: the cultural significance of wetland archaeology. UBC Press, Vancouver, British Columbia, Canada.

Olson, R. 1955. Notes on the Bella Bella Kwakiutl. Anthropological Records 14(5):259-347.

Olsson, P., C. Folke, and F. Berkes. 2004. Adaptive comanagement for building resilience in social-ecological systems. Environmental Management 34:75-90. http://dx.doi.org/10.1007/ $\underline{\text { s00267-003-0101-7 }}$

Paterson, K. J., and J. A. Neil. 1997. Effect of different growing techniques and substrate types on the growth and survival of the clams Tapes dorsatus (Lamarck) and Katelysia rhytiphora (Lamy). Aquaculture Research 28:707-715. http://dx.doi.org/10.1046/ j.1365-2109.1997.00915.x

Peterson, C. H. 1985. Patterns of lagoonal bivalve mortality after heavy sedimentation and their paleoecological significance. Paleobiology (12)2:139-153.

Peterson, G. D., S. R. Carpenter, and W. A. Brock. 2003. Uncertainty and management of multistate ecosystems: an apparently rational route to collapse. Ecology 84:1403-1411. http://dx.doi.org/10.1890/0012-9658(2003)084[1403:UATMOM]2.0. $\mathrm{CO} ; 2$

Pomeroy, J. A. 1980. Bella Bella settlement and subsistence. Dissertation. Department of Archaeology, Simon Fraser University, Burnaby, British Columbia, Canada. [online] URL: http://summit.sfu.ca/system/files/iritems1/3334/b12280008.pdf

Powell, M. 2012. Divided waters: Heiltsuk spatial management of herring fisheries and the politics of Native sovereignty. Western Historical Quarterly 43(4):463-484. http://dx.doi.org/10.2307/ westhistquar.43.4.0463

Quayle, D. B., and N. Bourne. 1972. The clam fisheries of British Columbia. Bulletin 179. Fisheries Research Board of Canada. Ottawa, Ontario, Canada.

Quayle, D. B., and G. F. Newkirk. 1989. Farming bivalve molluscs: methods for study and development. Advances in World Aquaculture, Volume 1. The World Aquaculture Society, Baton Rouge, Louisiana, USA. [online] URL: http://idl-bnc.idrc.ca/ dspace/handle/10625/4455

R Core Team. 2014. R: a language and environment for statistical computing. R Foundation for Statistical Computing, Vienna, Austria. [online] URL: https://www.r-project.org/

Rodnick, K., and H. W. Li. 1983. Habitat suitability index models: littleneck clam. FWS/OBS-82/10.59. U.S. Department of the Interior, Fish and Wildlife Service, Washington, D.C., USA. [online] URL: https://pubs.er.usgs.gov/publication/fwsobs82 $10 \quad 59$

Salomon, A. K., Kii'iljuus B. J. Wilson, E. White, N. Tanape, Sr., and T. M. Happynook. 2014. First Nations perspectives on sea 
otter conservation in British Columbia and Alaska: insights into coupled human-ocean systems. Pages 301-331 in S. Larson, J. L. Bodkin, and G. R. VanBlaricom, editors. Sea otter conservation. Academic, London, UK. http://dx.doi.org/10.1016/ b978-0-12-801402-8.00011-1

Schindler, D. E., R. Hilborn, B. Chasco, C. P. Boatright, T. P. Quinn, L. A. Rogers, and M. S. Webster. 2010. Population diversity and the portfolio effect in an exploited species. Nature 465(7298):609-612. http://dx.doi.org/10.1038/nature09060

Smith, B. D. 2011. General patterns of niche construction and the management of 'wild' plant and animal resources by smallscale pre-industrial societies. Philosophical Transactions of the Royal Society B 366:836-848. http://dx.doi.org/10.1098/ rstb.2010.0253

Stryd, A. D., G. Howe, and K. S. Preckel. 1993. Archaeological impact assessment Hakai Beach Resort, Calvert Island B.C. Archaeology Branch, Vancouver, British Columbia, Canada.

Suttles, W. 1960. Affinal ties, subsistence, and prestige among the Coast Salish. American Anthropologist 62:296-305. http://dx.doi. org/10.1525/aa.1960.62.2.02a00080

Suttles, W. 1987. Coping With abundance: subsistence on the northwest coast. Pages in W. Suttles, editor. Coast Salish essays. University of Washington Press, Seattle, Washington, USA.

Thornton, T. 1999. Tleikw Aaní, the "berried" landscape: the structure of Tlingit edible fruit resources at Glacier Bay, Alaska. Journal of Ethnobiology 19(1):27-48. [online] URL: https:// ethnobiology.org/sites/default/files/pdfs/JoE/19-1/Thornton.pdf

Thornton, T. F. 2015. The ideology and practice of Pacific herring cultivation among the Tlingit and Haida. Human Ecology 43 (2):213-223 http://dx.doi.org/10.1007/s10745-015-9736-2

Toba, D. R., D. S. Thompson, K. K. Chew, G. J. Anderson, and M. B. Miller. 1992. Guide to Manila clam culture in Washington. Washington Sea Grant Program, University of Washington Seattle, Washington.

Trosper, R. 2009. Resilience, reciprocity and ecological economics: northwest coast sustainability. Routledge, New York, New York, USA.

Trusler, S., and L. M. Johnson. 2008. "Berry patch" as a kind of place-the ethnoecology of black huckleberry in Northwestern Canada. Human Ecology 36:553-568. http://dx.doi.org/10.1007/ s10745-008-9176-3

Turner, N. J., M. Boelscher Ignace, and R. Ignace. 2000. Traditional ecological knowledge and wisdom of aboriginal peoples in British Columbia. Ecological Applications 10 (5):1275-1287. http://dx.doi.org/10.1890/1051-0761(2000)010[1275: tekawo]2.0.co;2

Turner, N. J. 2014. Ancient pathways, ancestral knowledge: ethnobotany and ecological wisdom of indigenous peoples of Northwestern North America. McGill-Queens University Press, Montreal, Quebec, Canada.

Turner, N. J., D. Deur, and D. Lepofsky. 2013. Plant management systems of British Columbia's First Peoples. B.C. Studies
179:107-113. [online] URL: http://ojs.library.ubc.ca/index.php/ bcstudies/article/view/184112

Turner, N. J., and J. T. Jones. 2000. Occupying the land: traditional patterns of land and resource ownership among First Peoples of British Columbia. In Constituting the commons: crafting sustainable commons in the new millennium. Eighth biennial conference of the International Association for the Study of Common Property, Bloomington, Indiana, USA. [online] URL: https://dlc.dlib.indiana.edu/dlc/handle/10535/1952

Turner, N. J., and H. V. Kuhnlein. 1987. Two important "root" foods of the northwest coast Indians: springbank clover (Trifolium wormskioldii) and pacific silverweed (Potentilla anserina ssp. pacifica). Economic Botany 36(4):411-432. http://dx. doi.org/10.1007/bf02862700

Tuner, N. J., R. Y. Smith, and J. T. Jones. 2005. 'A fine line between two nations': ownership patterns for plant resources among northwest coast indigenous peoples- implications for plant conservation and management. Pages 151-180 in D. Deur and N. J. Turner, editors. Keeping it living: traditions of plant use and cultivation on the northwest coast of North America. University of Washington Press, Seattle, Washington, USA.

Turner, N. J., and K. L. Turner. 2007. "Rich in food": traditional food systems, erosion and renewal in northwestern North America. Indian Journal of Traditional Knowledge 6(1):57-68.

White, E. A. F. 2006. Heiltsuk stone fish traps: products of my ancestors' labour. Thesis. Department of Archaeology, Simon Fraser University, Burnaby, British Columbia, Canada. [online] URL: http://summit.sfu.ca/item/4240

Williams, J. 2006. Clam gardens: aboriginal mariculture on Canada's west coast. New Star Books, Vancouver, British Columbia, Canada. 
Appendix 1. Clam length-weight regression

Equation A1.1. Formula for clam length-weight regression where $\mathrm{W}=$ weight, $\mathrm{L}=$ length, and alpha (a) and beta (b) are constants.

$\mathrm{W}=\mathrm{a} \times \mathrm{L}^{\mathrm{b}}$

Table A1.1. Values by species for clam length-weight regression.

\begin{tabular}{lll} 
Species & alpha & beta \\
\hline Macoma spp & 0.00002983 & 3.18 \\
S. giganteus & 0.000017734 & 3.52 \\
L. staminea & 0.000015696 & 3.64 \\
C. nuttallii & 0.00022 & 3.02
\end{tabular}


Appendix 2. Bivalve density

Figure A2.1. Actual (symbols) and predicted (line) density of butter clams (a, b), littleneck clams (c, d), Bentnose macoma (e, f) and total clams $(\mathrm{g}, \mathrm{h})$ as a function of intertidal height ( $\mathrm{m}$ above LLWLT) in clam gardens (green) and non-walled beaches (blue). Note variation in y-axes range among different bivalve species.
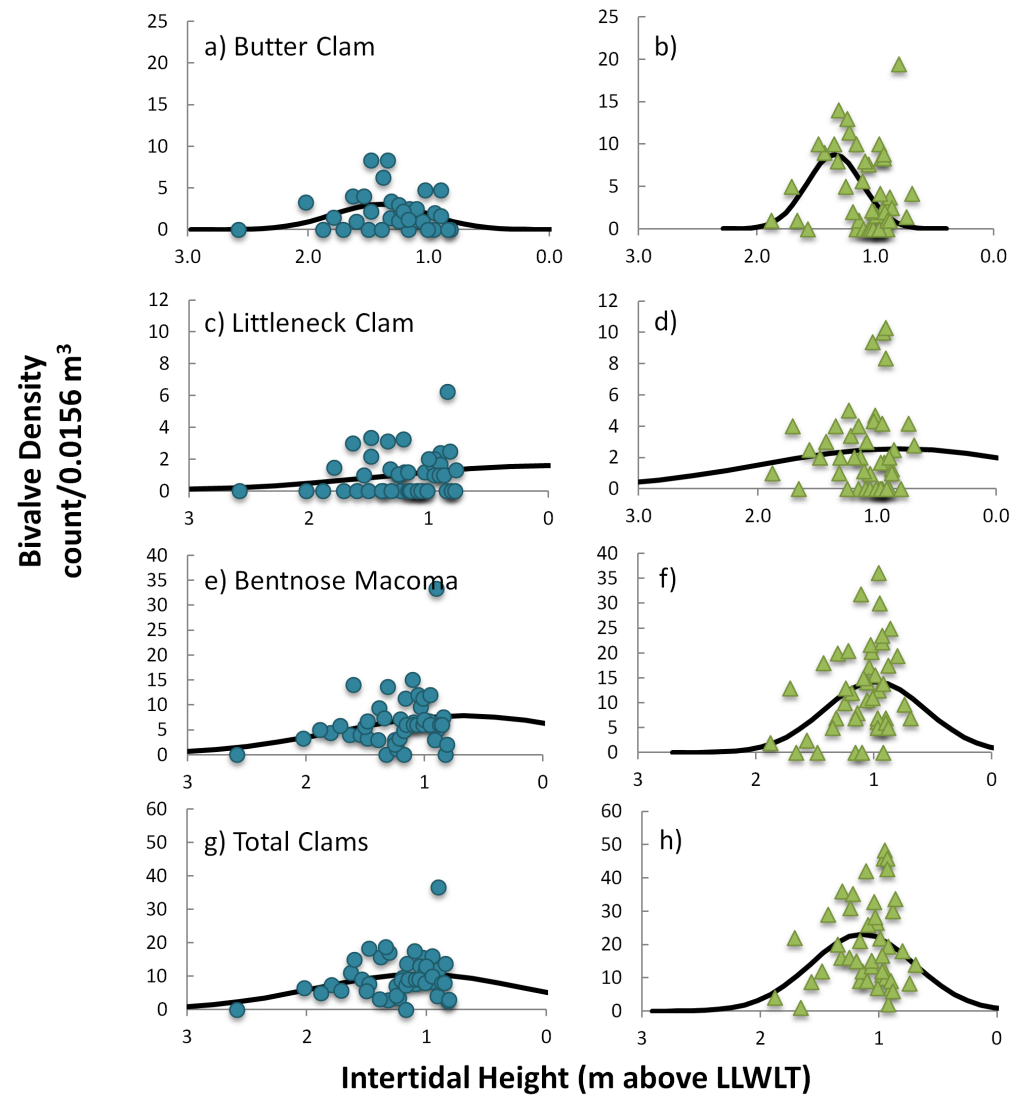
Equation A2.1. Formula for fitted gaussian curve where $y=$ response, $x=$ intertidal height, $\mathrm{a}=$ height, $\mu=$ mean, and $\sigma=$ standard deviation.

$y=a^{*} \exp \left(-0.5^{*}((x-\mu) / \sigma)^{2}\right)$

Table A2.1. Parameters for the modeled response of density (count $/ 0.0156 \mathrm{~m}^{3}$ ) of butter clam (Saxidomus gigantea), Bentnose macoma (Macoma spp.), littleneck clam (Leukoma staminea) and total clam species as a function of intertidal height. Each response was predicted by fitting a Gaussian curve (Eq. A4.1) to the data.

Predictive Gaussian Curves, 3 parameter: $y=a^{*} \exp \left(-0.5^{*}((x-\mu) / \sigma)^{2}\right)$

\begin{tabular}{|c|c|c|c|c|c|}
\hline Type & Response & a (height) & $\mu($ mean $)$ & $\begin{array}{l}\sigma \text { (standard } \\
\text { deviation) }\end{array}$ & $\begin{array}{l}\text { SSQ (sum of } \\
\text { squares) }\end{array}$ \\
\hline NW & S.g. Density & 3.05 & 1.39 & 0.39 & 163.91 \\
\hline $\mathrm{CG}$ & S.g. Density & 8.74 & 1.35 & 0.24 & 570.19 \\
\hline NW & L.s. Density & 1.60 & 0 & 1.30 & 74.90 \\
\hline $\mathrm{CG}$ & L.s. Density & 2.56 & 0.82 & 1.15 & 327.15 \\
\hline NW & M.spp. Density & 7.82 & 0.67 & 1.04 & 1277.24 \\
\hline $\mathrm{CG}$ & M.spp. Density & 14.24 & 0.99 & 0.43 & 3115.82 \\
\hline NW & All spp. Density & 10.61 & 1.05 & 0.87 & 1654.02 \\
\hline $\mathrm{CG}$ & All spp. Density & 23.10 & 1.14 & 0.44 & 6491.84 \\
\hline
\end{tabular}

